\title{
THE ROLE OF DECAFFEINATED COFFEE IN REDUCING THE RISK OF HYPERTENSION: A SYSTEMATIC REVIEW
}

Nurheni Sri Palupi*

Fatimah
Department of Food Science and Technology, Faculty of Agricultural Technology,

Bogor Agricultural University, Bogor, 16680, Indonesia

\section{ABSTRACT}

Hypertension or increased blood pressure is a degenerative disease with a high prevalence, as well as the biggest cause of premature death in the world. Meanwhile, coffee is a popular and most consumed beverage around the world. Coffee can harm some people with certain health problems including hypertension due to its caffeine content. Decaffeinated coffee is known to be an alternative for people with hypertension with reduced caffeine content up to $97 \%$. However, studies on the role of decaffeinated coffee in reducing the risk of hypertension are still varied indicating that a systematic review is needed. Hence, this study summarizes the evidence related to the role of decaffeinated coffee in reducing the risk of hypertension by using Preferred Reporting Items for Systematic Reviews and Meta-Analyses (PRISMA). The inclusion criteria for scientific journals were determined based on Participants, Intervention, Control, and Outcome (PICO). The search using boolean operation resulted in 13 research articles for data extraction. The result revealed that decaffeinated coffee could decrease or did not give any effect on blood pressure or another biological hypertension marker compared to regular coffee.

Keywords: Coffee, decaffeinated coffee, hypertension, regular coffee, systematic review

\section{ABSTRAK}

Hipertensi atau peningkatan tekanan darah merupakan penyakit degeneratif dengan prevalensi tinggi, sekaligus penyebab kematian dini terbesar di dunia. Sedangkan kopi merupakan minuman yang populer dan paling banyak dikonsumsi di seluruh dunia. Kopi dapat membahayakan sebagian orang dengan masalah kesehatan tertentu termasuk hipertensi karena kandungan kafeinnya. Kopi tanpa kafein diketahui bisa menjadi alternatif bagi penderita hipertensi dengan kandungan kafein yang berkurang hingga 97\%. Namun, penelitian tentang pengaruh kopi dekafeinasi dalam menurunkan risiko hipertensi masih bervariasi, mengindikasikan perlu dilakukan tinjauan sistematis. Penelitian ini menggunakan metode tinjauan sistematis untuk meringkas hasil penelitian terkait efek kopi tanpa kafein dan kopi biasa terhadap risiko hipertensi menggunakan Preferred Reporting Items for Systematic Reviews and Meta-Analyses (PRISMA). Kriteria inklusi untuk jurnal ilmiah ditentukan berdasarkan Peserta, Intervensi, Pengendalian, Hasil (PICO). Pencarian menggunakan operasi boolean menghasilkan 13 artikel penelitian untuk ekstraksi data. Hasil penelitian menunjukkan bahwa kopi tanpa kafein memberikan efek yang bervariasi antara dapat menurunkan atau tidak berpengaruh pada tekanan darah atau penanda hipertensi biologis lainnya dibandingkan kopi biasa.

Kata kunci: Hipertensi, kopi, kopi biasa, kopi tanpa kafein, tinjauan sistematis
Article Information

Article Type: Review Paper Journal Type: Open Access Volume: 2 Issue 2

Manuscript ID v2n2523-1

Received Date 17 December 2020

Accepted Date

22 February 2021

Published Date

26 February 2021

DOI: 10.33555/jffn.v2i2.60

Corresponding author: Nurheni Sri Palupi Bogor, Indonesia, 16680 Email: hnpalupi@apps.ipb.ac.id

Citation:

Palupi, N.S., Fatimah. 2021. The role of decaffeinated coffee in reducing the risk of hypertension: a systematic review. J. Functional Food \& Nutraceutical, 2(2), pp.99-116

Copyright: $\odot 2021$ Swiss German University. This is an open-access article distributed under the terms of the Creative Commons Attribution 4.0 International License, which permits unrestricted use, distribution and reproduction in any medium, distribution and reproduction in any medium,
provided the original author and source are credited. 


\section{INTRODUCTION}

Coffee is a widely consumed beverage and is popular throughout the world (Butt et al., 2011). Coffee is known as a regular beverage with extensive health benefits, such as increasing the physical and mental performance of its regular drinkers (Zhang et al., 2011). Besides, consumption at the right dose per day indicates a reduction in risk from various health risks (Poole $e t$ al., 2017). However, coffee can harm some people with certain health problems, such as hypertension. This is caused by the high caffeine content in coffee (Geleijnse, 2008). A method called decaffeination is developed in order to reduce the risk of increased blood pressure and other negative effects due to caffeine. This method is aimed to to reduce the caffeine content in coffee (Butt et al., 2011).

Decaffeinated coffee is known to be an alternative for people with hypertension, or people who have a low tolerance for caffeine because of the reduced caffeine content of up to $97 \%$ (Kumar and Ravishankar, 2009). At present, an updated study in the form of a systematic review needs to be conducted to evaluate the differences in the impact of decaffeinated and regular coffee on the risk of hypertension, given that coffee is considered a lifestyle trend.

\section{Coffee and health}

Coffee is known to provide health benefits, including an anti-inflammatory, antifibrotic, and anticancer (Poole et al., 2017). Roasted coffee beans which are subsequently consumed as drinks have various bioactive components, including caffeine, chlorogenic acid, diterpenes, cafestol, and kahweol (Poole et al., 2017).

The coffee processing starting from postharvest handling (fermented or natural), roasting level, and brewing methods affect the content of bioactive compounds in coffee (Hameed et al., 2018). In addition to these factors, the human body's response to bioactive components in coffee also influences the bioavailability and health effects of coffee (Yang et al., 2010).
Coffee contains approximately $43 \%$ carbohydrates (70-85\% polysaccharides, arabinogalactans, mannans, glucans, sucrose, reducing sugars, lignins, and pectins), $10-15 \%$ lipids (75\% triacylglycerols, $18,5 \%$ esters of diterpenes, free sterols, sterol glucosides, waxes, tocopherols, and phosphatides), $7,5-10 \%$ protein, another nitrogenous compound (1\% caffeine, $0,7-1 \%$ trigonelline, and 0,01-0,04\% nicotinic acid), 25\% melanoidins, $3,7-5 \%$ minerals and organic and inorganic acids, and esters (1-4\% chlorogenic acids and other phenolic compounds, 1,4-2,5\% aliphatic acids and quinic acid and $<0,3 \%$ inorganic acids). Those reported data regarding the amounts of nutrients could be varied due to variability in the terms of raw material production, processing, and brewing, which lead to the final product (the brew) (Farah, 2018).

\section{Caffeine and hypertension}

Hypertension is a factor of many chronic diseases such as coronary artery disease, stroke, heart failure, and kidney disease. In patients with hypertension, an increase or decrease in blood pressure can have a significant impact on various health conditions (Rhee et al., 2016). Also, several physiological and biological markers are referred to as indicators for incidents of hypertension, namely urinary catecholamines, and serum cholesterol. Lifestyle factors are factors that greatly influence the high prevalence of hypertension in the world. One lifestyle that is quite highlighted is the consumption of caffeine, both naturally or synthetically (Turnbull et al., 2017). Coffee as a major caffeine beverage consumed around the world contains some bioactive compounds, including caffeine. Caffeine can increase blood pressure and hypertension risk because it has a pressure effect and the ability to increase vascular resistance (Lovallo et al., 2004). However, the effect of caffeine can vary in each person due to genetic factors, and the tolerance of body to caffeine (Rhee et al., 2016).

Caffeine consumption is a concern for authorities and regulatory bodies, given the impact that can vary between groups. Caffeine is thought to harm pregnant and lactating women, children and adolescents, young adults, and people with mental 
health and cardiovascular problems (Temple et al., 2017).

\section{Decaffeinated coffee}

Decaffeinated coffee is coffee beans that have undergone a process of caffeine reduction. The decaffeination process can be carried out using solvents such as water, organic solvents, or carbon dioxide (De Paula and Farah, 2019). Decaffeinated coffee aims to reduce caffeine levels and as an alternative for people with certain health problems such as hypertension, and low caffeine tolerance. The decaffeination process is done before the coffee beans are roasted and ground, so that the nutrients from decaffeinated coffee are almost similar to regular coffee, except for the caffeine content. The difference that arises after decaffeinated coffee is the aroma and taste of coffee beans become milder, and a slight color change can occur depending on the process method used (De Paula and Farah, 2019).

The caffeine content in decaffeinated coffee is around $0-7 \mathrm{mg} / \mathrm{cup}(180 \mathrm{~mL})$, while that in regular coffee is $70-140 \mathrm{mg} / 180 \mathrm{~mL}$ (Ramalakshmi and Raghavan, 1999). Decaffeinated coffee contains antioxidants which can be lower by around $15 \%$. This can be due to the decaffeination process which dissolves polar or nonpolar bioactive compounds in coffee beans. The dominant bioactive compounds in decaffeinated coffee are hydrocinnamic acids and polyphenols. Besides, decaffeinated coffee also has several micronutrients such as vitamins and minerals (Ramalakshmi and Raghavan, 1999). Mineral such potassium found in decaffeinated coffee has a modest blood pressure-lowering effect in normotensive person with low dietary intake (Frank et al., 1998).

\section{Decaffeination process}

Decaffeination aimed to minimize the negative physiological effect of caffeine and still keep the desirable flavor and aroma attributes of coffee (Heilmann, 2008). The decaffeination procedures nowadays are divided into decaffeination with the use of chemical solvent for extraction a chemical solvent, water, and supercritical $\mathrm{CO}_{2}$ (Heilmann, 2008).
Decaffeination with chemical solvent requires a solvent that is virtually immiscible with water to maintain the water-soluble components from the bean, especially the flavor precursor. There are several considerations of using a chemical solvent, such as relatively low investment and operating cost, and high quality. More than $50 \%$ of the worldwide capacity of decaffeination is based on the chemical solvent (Heilmann, 2008). A variety of organic solvents are suitable for this type of extraction, but methylene chloride $\left(\mathrm{CH}_{2} \mathrm{Cl}_{2}\right)$ and ethyl acetate are mostly used. With organic solvent decaffeination, the beans are firstly contacted with steam and water to increase their moisture content up to 25 or even $40 \mathrm{wt} \%$. After that moisture content is reached, the extraction process begun within the fixed beds (e.g percolation, column batteries, carousel extractors) or in an agitated system (e.g rotating drums). The rate-controlling or intense bean agitation does not necessary since the diffusion of caffeine in the beans is rather slow (Pietsch, 2017).

The water decaffeination process developed as an alternative to chemical solvent extraction due to anticipation of DCM being banned by the food authorities. However, DCM is still approved by the relevant organization as a food solvent. Water decaffeination is relatively much more expensive in investment but still used by around $22 \%$ of the world coffee decaffeination process since it resulted in clearer and naturally decaffeinated coffee (Pietsch, 2017). The lack of water decaffeination is including the limited selectivity of water, which could lead to the extraction of the non-caffeine compound like sugar. To solve this problem, there are two principal ways, either to hinder the water from extracting non-caffeine coffee soluble compound or to incorporate the extracted soluble into the green beans (Heilmann, 2008).

The process of decaffeination using supercritical $\mathrm{CO}_{2}$ is generally like the other process, starting from the swelling of the beans with water and then extraction in the percolation columns with highpressure vessels commonly at $30 \mathrm{MPa}$. Heilman (2008) proposed three methods could be used for decaffeination using supercritical $\mathrm{CO}_{2}$. The first one is the moistened green beans are mixed with 
the $\mathrm{CO}_{2}$ stream. The mixture will pass into a washing tower where the caffeine is absorbed in water. This process will be recycled up to 10 hours long, or until almost all of the caffeine is dissolved in the water.

\section{METHOD}

This study uses a systematic review method to summarize the evidence related to the effect of decaffeinated and regular coffee on the risk of hypertension. This research will use Preferred Reporting Items for Systematic Reviews and MetaAnalyses (PRISMA), which are the recent guidelines to select literature included in the systematic review. The process of article selection was shown in Figure 1.

\section{Inclusion and exclusion criteria}

The inclusion criteria for scientific journals were determined based on Participants, Intervention, Control, Outcome (PICO). Meanwhile, the exclusion criteria will be nonhuman study, use none of the regular and decaffeinated coffee, did not use the control, and measures none of the physiological and biological markers of hypertension. The PICO for this review is shown in Table 1.

Table 1. PICO of the systematic review

\begin{tabular}{ll}
\hline \multicolumn{1}{c}{ Inclusion Factors } & \multicolumn{1}{c}{ Criteria } \\
\hline Participants (P) & Human \\
\hline \multirow{3}{*}{ Intervention (I) } & $\begin{array}{l}\text { Administration of } \\
\text { decaffeinated and regular } \\
\text { coffee, or one of them }\end{array}$ \\
\hline & Nonhabitual coffee drinkers, \\
& regular coffee, or non-coffee \\
bontrol (C) & Physioges \\
\hline & hypertension marker after \\
Outcomes (O) & administration of coffee \\
\hline
\end{tabular}

\section{Databases and search terms}

In this systematic review, the relevant scientific articles were searched in several databases such as PubMed, Science Direct, Cochrane, Embase, and Google Scholar since those databases are the most common to find publications regarding the topic. Also, in this review, the relevant article will be searched using the boolean search. Boolean search is a structured search where users can include several operations (AND, OR, NOT) for specific search results. This method aims to find the relevant subject content in journal articles. In search of the references, the boolean operation used is "Decaffeinated coffee" AND "regular coffee" AND ("hypertension" OR "blood pressure"). Besides, all studies of humans published up to 20 August 2020 were eligible due to the lack of articles with the desired topic in the early 10 years.

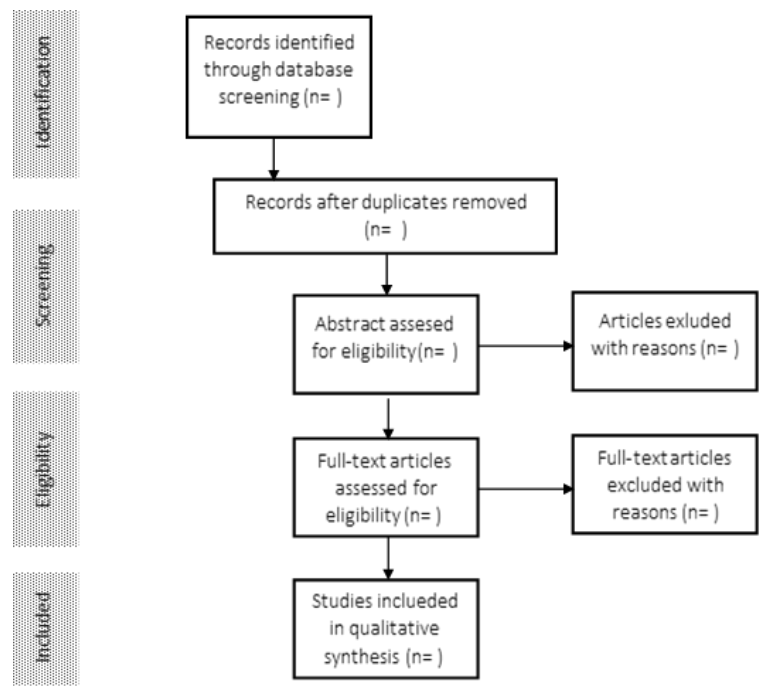

Figure 1. PRISMA guideline for systematic review

\section{Data extraction}

Data extraction is a process to gather the core information from the scientific articles which pass the screening process. Data extraction was conducted after the screening of duplication and abstract relevance. The core information extracted referred to Cochrane Guidelines for Systematic Review 2019. The data extraction process 
including the proofreading of the full-text article, and summarize the information with a systematic review software management. The systematic review management tools used in this review was Ms. Excel with a customized workbook with the rows and columns designed according to the information being extracted. The type of information was determined based on relevance with the study topic and scientific field of the author.

\section{RESULTS AND DISCUSSION}

Entering the boolean operation with terms consist of "decaffeinated coffee" AND "regular coffee" AND ("hypertension" OR "blood pressure") in databases such as PubMed, Cochrane, Embase, and Google Scholar resulted in 47 published articles as shown in Figure 2. These articles then screened for duplicate entries. This process resulted 46 articles. The abstract of these articles was then screened for specific contexts including the type of study, interventions, participants, time, and outcome. This step then removed 12 articles. The remaining (typo error, remaining) 34 articles were then screened based on full-text proofreading for specific context including the clarity of methodology. The clarity of the methodology means the research articles give a well chronological aspect started from the selection of participants (ethical clearance, health condition parameters), source of materials (regular and decaffeinated coffee), and outcome of studies (should be for hypertension parameters; blood pressure, heart rate, pulse rate, catecholamines). These screening steps then removed 12 articles. The remaining (the remaining, typo error) 13 articles are further included for qualitative synthesis. The result of the qualitative synthesis is shown in Table 2.

\section{DISCUSSION}

\section{Search results and study characteristics}

After passing the screening process to exclude the duplication, and abstract relevance, thirteen scientific articles were obtained for further qualitative analysis. The thirteen scientific articles were published between 1983 and 2019. The study type of thirteen scientific articles consists of five double-blind trials, one single-blind study, two cohort studies, one prospective study, and one experimental analytic research. Total 109,036 participants were included in this systematic review with varied research duration, from one day up to 10 years. The health condition of participants also varied but was limited to smoking habits, coffee drinking habits, and hypertension diagnoses history. Figure 3 showing the profile of 13 scientific articles included in this review.

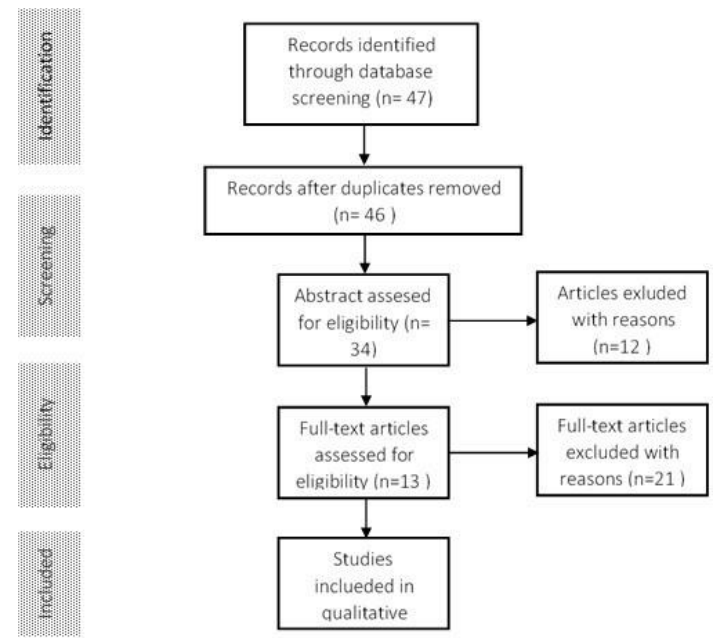

Figure 2. The results of articles based on boolean search from several databases

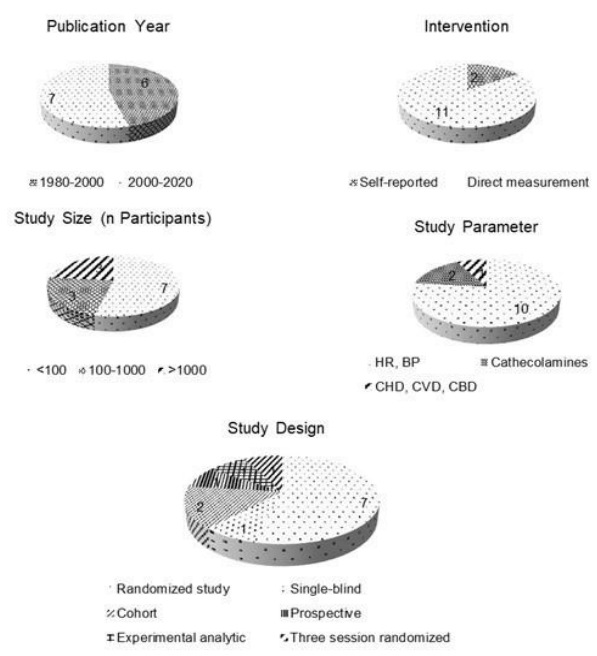

Figure 3. The profile of scientific articles included in qualitative analysis 
Table 2. The results of data extraction from 13 studies included in the systematic review

\begin{tabular}{lllll}
\hline Number & Year & Author & Subjects (n) & Caffeine Content \\
\hline
\end{tabular}

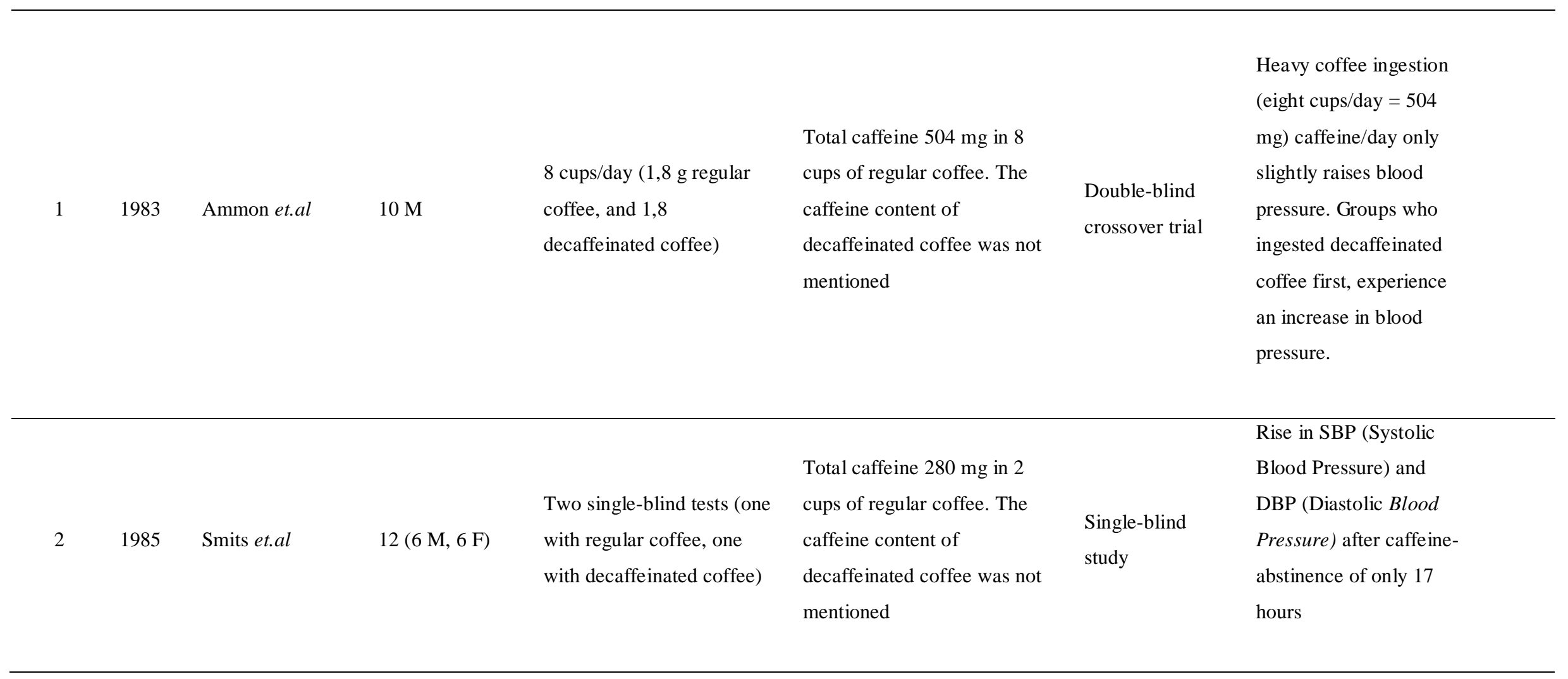




\begin{tabular}{|c|c|c|c|c|c|c|c|}
\hline Number & Year & Author & Subjects (n) & Intervention & Caffeine Content & Study type & Main Outcomes \\
\hline 3 & 1988 & Prakash et.al & 9 (7 M, 2 F) & 2 cups in fasting state & $\begin{array}{l}\text { Total caffeine } 175 \mathrm{mg} \text { in } 2 \\
\text { cups of regular coffee, and } 6 \\
\mathrm{mg} \text { in } 2 \text { cups of decaffeinated } \\
\text { coffee }\end{array}$ & $\begin{array}{l}\text { Double-blind } \\
\text { randomized } \\
\text { study }\end{array}$ & $\begin{array}{l}\text { Two cups of } \\
\text { decaffeinated coffee had } \\
\text { no adverse } \\
\text { cardiovascular effect in } \\
\text { the healthy subject }\end{array}$ \\
\hline
\end{tabular}

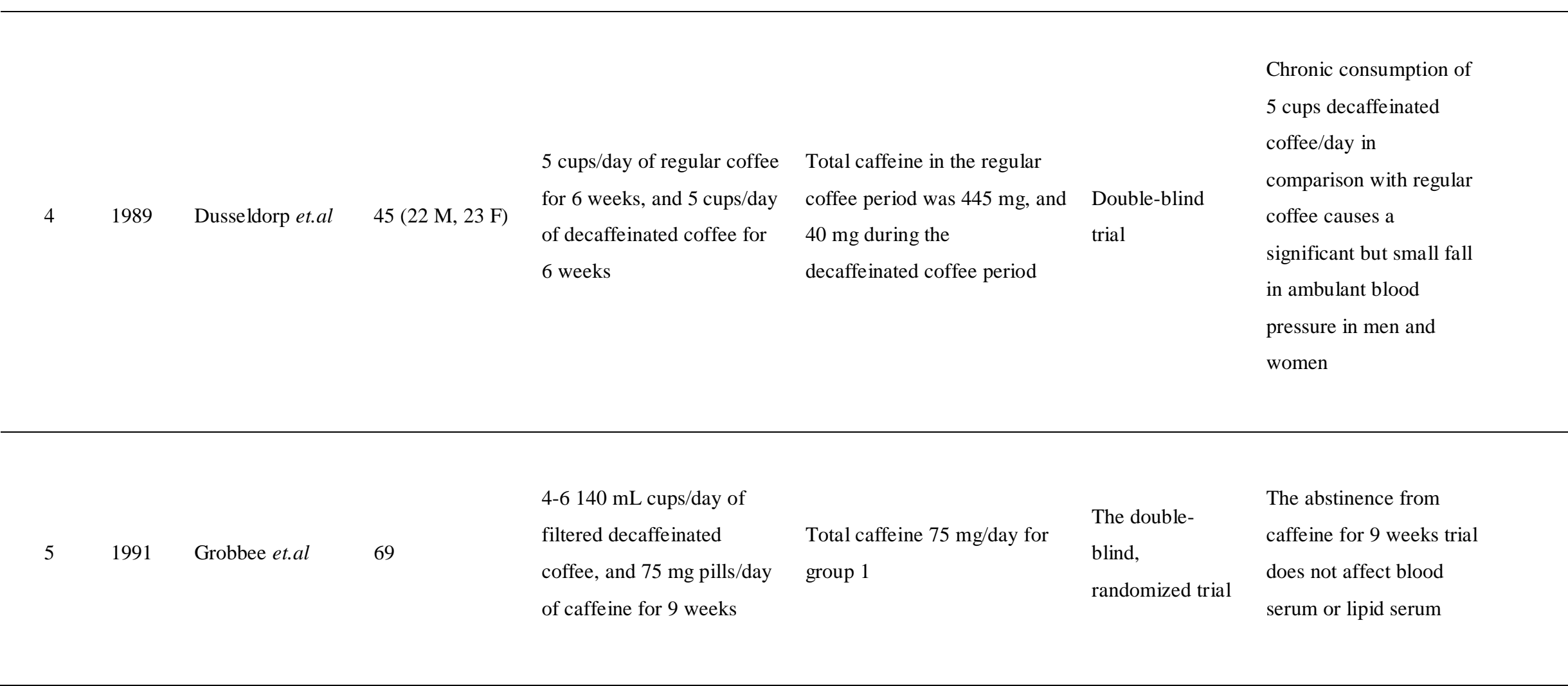




\begin{tabular}{|c|c|c|c|c|c|c|c|}
\hline Number & Year & Author & Subjects (n) & Intervention & Caffeine Content & Study type & Main Outcomes \\
\hline 6 & 1994 & Superko et.al & $186 \mathrm{M}$ & A cup/day coffee ingestion & Not specified & Randomized trial & $\begin{array}{l}\text { Statistically no } \\
\text { significant difference in } \\
\text { blood pressure between } \\
\text { three group }\end{array}$ \\
\hline 7 & 2005 & Karatzis et.al & $16(8 \mathrm{M}, 8 \mathrm{~F})$ & $\begin{array}{l}\text { A cup of warm instant } \\
\text { coffee containing } 80 \mathrm{mg} \\
\text { caffeine, or a cup of } \\
\text { decaffeinated coffee within } \\
10 \text { minutes, on } 2 \text { different } \\
\text { days, a week apart }\end{array}$ & $\begin{array}{l}80 \mathrm{mg} \text { caffeine/cup for regular } \\
\text { coffee. Caffeine coffee of } \\
\text { decaffeinated coffee was not } \\
\text { mentioned. }\end{array}$ & $\begin{array}{l}\text { Randomized, } \\
\text { double-blind, } \\
\text { crossover }\end{array}$ & $\begin{array}{l}\text { No change of aortic } \\
\text { blood pressure was } \\
\text { observed following } \\
\text { consumption of } \\
\text { decaffeinated coffee }\end{array}$ \\
\hline 8 & 2008 & Greenberg et.al & 1354 & $\begin{array}{l}\text { Subjects asked how many } \\
\text { cups each day of regular } \\
\text { coffee, decaffeinated } \\
\text { coffee, regular tea, and } \\
\text { decaffeinated tea intake }\end{array}$ & Not specified & Cohort study & $\begin{array}{l}\text { Regular coffee } \\
\text { consumption showed a } \\
\text { significant negative } \\
\text { association with CHD, } \\
\text { but not CVD pf CBD. } \\
\text { All decaffeinated } \\
\text { beverages were not } \\
\text { significantly associated } \\
\text { with CVD, CHD, or } \\
\text { CBD mortality }\end{array}$ \\
\hline
\end{tabular}




\begin{tabular}{|c|c|c|c|c|c|c|c|}
\hline Number & Year & Author & Subjects (n) & Intervention & Caffeine Content & Study type & Main Outcomes \\
\hline 9 & 2012 & Renda et.al & $110 \mathrm{M}$ & $\begin{array}{l}\text { Administration of } 40 \mathrm{~mL} \text { of } \\
\text { either decaffeinated coffee } \\
\text { preparation plus } 3 \mathrm{mg} \text {, or } \\
\text { decaffeinated coffee alone }\end{array}$ & Not specified & $\begin{array}{l}\text { The double- } \\
\text { blind, } \\
\text { randomized trial }\end{array}$ & $\begin{array}{l}\text { Compared with } \\
\text { decaffeinated coffee, } \\
\text { regular coffee was } \\
\text { associated with a mean } \\
\text { significant increase in } \\
\text { SBP }\end{array}$ \\
\hline 10 & 2013 & Azuamah et.al & 103 & $\begin{array}{l}\text { Administration of } 1 \text { cup } \\
\text { coffee ( } 3,6 \mathrm{~g} \text { decaffeinated } \\
\text { coffee in } 200 \mathrm{~mL} \text { of water) }\end{array}$ & Not specified & $\begin{array}{l}\text { Experimental } \\
\text { analytic research }\end{array}$ & $\begin{array}{l}\text { The mean systolic } \\
\text { pressure reduced after } \\
\text { decaffeinated coffee } \\
\text { ingestion }\end{array}$ \\
\hline 11 & 2015 & $\begin{array}{l}\text { Zimmermann- } \\
\text { Viehoff et.al }\end{array}$ & $77(74 \% \mathrm{~F})$ & $\begin{array}{l}\text { Three laboratory session in } \\
\text { randomized order } \\
\text { (espresso, decaffeinated } \\
\text { espresso, and warm water) }\end{array}$ & $\begin{array}{l}\text { The caffeine content of } \\
\text { regular espresso is } 256,8 \\
\mathrm{mg} / \text { cup. The caffeine content } \\
\text { of decaffeinated espresso is } 36 \\
\mathrm{mg} / \text { cup }\end{array}$ & $\begin{array}{l}\text { Randomized } \\
\text { three-session } \\
\text { crossover design }\end{array}$ & $\begin{array}{l}\text { In habitual coffee } \\
\text { consumers, the vagally } \\
\text { mediated HRV was } \\
\text { significantly lower after } \\
\text { consumption of } \\
\text { decaffeinated espresso } \\
\text { compared to a regular } \\
\text { espresso. Increases of } \\
\text { SBP were only found in } \\
\text { the non-habitual } \\
\text { consumers }\end{array}$ \\
\hline
\end{tabular}




\begin{tabular}{|c|c|c|c|c|c|c|c|}
\hline Number & Year & Author & Subjects (n) & Intervention & Caffeine Content & Study type & Main Outcomes \\
\hline 12 & 2016 & Rhee et.al & $\begin{array}{l}93676 \text { person- } \\
\text { years follow up }\end{array}$ & $\begin{array}{l}\text { Self-reported } \\
\text { questionnaires of type, } \\
\text { amount, and total caffeine } \\
\text { consumption }\end{array}$ & Not specified & $\begin{array}{l}\text { Prospective } \\
\text { study }\end{array}$ & $\begin{array}{l}\text { Regular coffee, } \\
\text { decaffeinated coffee, } \\
\text { and caffeine are not risk } \\
\text { factors for hypertension } \\
\text { in menopausal women }\end{array}$ \\
\hline 13 & 2019 & Navarro et.al & 13369 & $\begin{array}{l}\text { Validated semi-quantitative } \\
\text { food frequency } \\
\text { questionnaire }\end{array}$ & Not specified & Cohort study & $\begin{array}{l}\text { Coffee consumption } \\
\text { (either regular or } \\
\text { decaffeinated) was not } \\
\text { significantly associated } \\
\text { with the risk of } \\
\text { hypertension }\end{array}$ \\
\hline
\end{tabular}




\section{The effect of regular and decaffeinated coffee on the risk of hypertension}

\section{Observational studies}

A cohort study was conducted by Greenberg et al. (2008) to evaluate the relationship between regular coffee consumption, cardiovascular disease, and heart valve disease in the elderly. The study carried out 1,354 subject participants. The participants were taken from a previous study in 1948 by Framingham. The subject participants were all asked how many cups each day of regular coffee, decaffeinated coffee, regular tea, and decaffeinated tea intake during the 10.1 average years of follow up. Subjects with any missing data were excluded from the analysis and resulted in 1,354 subjects aged between 65.4 and 96.6 years. Beverage intake, either regular or decaffeinated coffee, was determined by Food-Frequency Question (FFQ). The subjects were asked how many cups of regular and decaffeinated coffee intake each day. Besides, the dosage of beverages intake was categorized as any and no cups each day. The findings suggested that the association between regular coffee consumption and decreased CHD (Coronary Heart Disease) mortality risk may have been related to the effect against the development of heart valve disease. In subjects with BP (Blood Pressure) less than the Stage 1 hypertension level and no heart valve disease diagnoses at baseline, consumption of any regular coffee was associated with a $71 \%$ decreased risk of CHD mortality and 56\% decreased risk of valve disease. Therefore, generally, the study concluded that regular coffee consumption showed a significant negative association with CHD, but not CVD (Cardiovascular Disease) and CBD (Cerebrovascular Disease).

A prospective study by Rhee et al. (2016) was done in the United States with 93,676 person-years follow-up. This study aimed to investigate the relation between coffee and caffeine consumption and the risk of hypertension in postmenopausal women. The subject participants of this study were postmenopausal women aged 50-79 years who enrolled in the study at 40 clinical centers nationwide from September 1993 to December 1998. However, this study excluded women with hypertension at baseline (SBP or DBP $\geq 140 \mathrm{mmHg}$ or $\geq 90 \mathrm{mmHg}$ respectively), and women being treated for hypertension. The participants were able to select several categories for the dosage namely 1 cup/day, 2-3 cups/day, and $\geq 6$ cups/day for regular or decaffeinated coffee. The data revealed that no clinically meaningful differences in baseline SBP (Systolic Blood Pressure) and DBP (Diastolic Blood Pressure) across regular coffee intake categories. This study also revealed that higher total caffeine intake was associated with a lower mean SBP. In general, this study also suggested that no consistent association was found between regular and decaffeinated coffee intake and the risk of hypertension.

Navarro et al. (2019) conducted a cohort study with 13,369 healthy subject participants. All of the participants were asked to fill the validated semiquantitative Food Frequency Questionaire (FFQ) and allowed to choose coffee consumption categories by following options; never or seldom, $<1$ cup/day and, >2 cups/day. Also, the FFQ asked the participants included several factors such as socio-demographic factors (sex, age, marital and employment status, university degree), anthropometric variables (weight, height), healthrelated habits (smoking status, alcohol consumption, physical activity), and clinical variables (use of medication, CHD history of personal and family, cancer, and other diseases). Hazard analysis was conducted to obtain the relation between the three coffee drinking habits with those variables. The results revealed a significant interaction between regular coffee consumption and sex, where women who consumed at least 2 cups of regular coffee per day showed a Hazard Ratio of 0.74 compared to women who never or seldom drinking regular coffee. The researcher found that no significant association was found between regular coffee consumption with those with higher adherence to the Mediterranean diet and among men. The analysis also showed that consumption of decaffeinated coffee did not significantly associate with sex, age, smoking, or adherence Mediterranean diet, as well as the incidence of hypertension. 


\section{Experimental studies}

Smits (1985) conducted a single-blind study with 12 subject participants, which consist of 6 males and 6 females. The subject participants included in the study were all used to consume coffee with daily intake ranged between 3 up to 10 cups/day. During the treatment period, 2 cups/day of regular or decaffeinated coffee were administered. Two cups of regular coffee were equal to $280 \mathrm{mg}$ caffeine, while the total caffeine in decaffeinated coffee was not mentioned. All of the subjects underwent two single-blind tests, one with regular coffee, and one with decaffeinated coffee in a random sequence. The parameter related to the risk of hypertension used in this research consist of SBP, DBP, Heart Rate (HR), and Forearm Blood Flow (FBF).

In this research, the subjects were asked to abstain from caffeine for 17 hours and to smoke for 4 hours before start the treatment. The treatment started after 20 minutes rest period. After that, in the next 20 minutes, SBP, DBP, HR, and FBF were measured every 5 minutes. The results found that there are differences in the SBP, DBP, HR, and FBF before and after coffee ingestion. There was a significant rise of SBP and DBP after coffee ingestion of $4.4 \pm 1.4 \%$ and $11.8 \pm 2.5 \%$. On the other hand, HR decreased within $8.4 \pm 3.1 \%$. After decaffeinated coffee ingestion, the DBP showed a rise of $4 \pm 1.4 \mathrm{mmHg}$, but SBP and HR did not alter significantly. Besides, statistical analysis showed that the coffee induced rise of DBP was significantly higher than the increase of DBP after decaffeinated coffee $(P<0,05)$. Meanwhile, the mean FBF remains unchanged in both tests. Catecholamines were also measured in this research and it shows that regular coffee induces a rise of plasma catecholamines significantly higher than the changes after decaffeinated coffee.

Ammon et al. (1983) conducted a double-blind cross-over study with ten male participants. The participants included in the research were aged between 20 and 30 years old, nonsmokers, and used to coffee. The participants in this study were divided into two main groups. The first group was the participants firstly treated with 8 cups/day of decaffeinated coffee during a half period of research ( 2 weeks), then the rest half period was treated with $8 \mathrm{cups} / \mathrm{day}$ of regular coffee. The second group was the participants firstly treated with 8 cups/day of regular coffee for a half period of research ( 2 weeks), then the rest half period was treated with 8 cups/day of decaffeinated coffee. Therefore, the total duration of this research is 5 weeks, which is divided into a week of the control period, and four weeks of the treatment period. The total caffeine content for a daily consumption is $504 \mathrm{mg}$ for regular coffee. The total caffeine content for decaffeinated coffee is not mentioned.

Blood pressure, heart rate, and urinary catecholamines were measured as parameters in this study. This study shows that the ingestion of regular coffee led to an immediate change in mean blood pressure by $6 \mathrm{mmHg}$ between control and treatment periods in the second group. Besides, it also shows the change in mean blood pressure by 4 $\mathrm{mmHg}$ between control and treatment periods in the first group. Besides, the significant differences between the first and second groups were observed only during the first 3 or 5 days after switching to regular coffee. The participants who digest decaffeinated coffee first followed by regular coffee showed a significant increase in blood pressure. Meanwhile, the participants who digest regular coffee first followed by decaffeinated coffee did not show a difference in blood pressure.

Other parameters measured in this article are heart rate and urinary catecholamines. The initial heart rate of the participants is $74 \pm 3$ beats/min for the first group and $65 \pm 5$ beats/min for the second group. These results are considered as not statistically different $(\mathrm{P}>0,1)$. A significant increase in heart rate was observed in neither group. The heart rate increase was obtained after switching to regular coffee. These findings indicated that regular coffee consumption might increase the heart rate compared to decaffeinated coffee. Meanwhile, the urinary catecholamines level measured in this research was neither observed with significant difference in the first or second group.

Prakash and Kaushik (1988) conducted a doubleblind randomized study to evaluate the acute effect of decaffeinated coffee on heart rate, blood 
pressure and exercise performance in healthy subjects. This study included 9 subject participants, which consist of 7 males and 2 females. Five of the subject participants included in the study drank no coffee normally, while the remaining four drank 35 cups/day. Also, 6 of 9 participants were nonsmokers, two smoke a half pack a day, and one smoked one pack a day. There is no group specification in this study. Each of the study participants must drink two cups of coffee in a fasting state. The fasting state in this study refers to the resting time before the participants start the exercise. The caffeine content of regular coffee given to the participants was $175 \mathrm{mg}$, while two cups of decaffeinated coffee contain $6 \mathrm{mg}$ of caffeine. After ingestion of the coffee, each of the participants exercised on a treadmill.

The parameter used in this study was blood pressure value which was measured with each increase in the workload. This measurement was conducted immediately after recovery, and at 1, 3, 5,10 , and 14 minutes after the conclusion of the exercise. The result of this study found that the heart rate/min before, after 30 minutes, and the peak of the exercise was different between regular and decaffeinated coffee treatment.

Before coffee ingestion, the mean heart rate/min value of regular coffee drinkers was slightly higher compared to decaffeinated coffee drinkers (74.7 \pm 10.5 and $72.3 \pm 7.2$ ). Thirty minutes of exercise and after coffee ingestion, the mean heart rate/min value of regular coffee was higher compared to decaffeinated coffee drinkers $72.3 \pm 14.5$ and 68.8 \pm 7.8 ).

At the peak of exercise, the mean heart rate/min value of regular coffee drinkers is also higher compared to decaffeinated coffee drinkers (174 \pm 14.6 and $173 \pm 15.5)$. The mean SBP value before coffee ingestion, the regular coffee drinkers showed a lower mean SBP value compared to decaffeinated coffee drinkers. However, after 30 minutes of coffee ingestion, the mean SBP value of regular coffee drinkers were higher compared to decaffeinated coffee drinkers, and the same for the mean SBP value at the peak of exercise. The mean DBP value of regular coffee drinkers at measurement before, after 30 minutes, and the peak of exercises were all lower compared to decaffeinated coffee drinkers. In conclusion, this study generally suggested that regular or decaffeinated coffee give a similar cardiovascular effect in healthy subjects even though there was no medical basis to claim the better option between regular or decaffeinated coffee.

Van Dusseldorp et al. (1989) published a doubleblind study to evaluate the effect of decaffeinated and regular coffee on blood pressure. This study carried out 45 participants which consist of 22 males, and 23 females. All of the participants included in the study were aged between 17 and 45 years. The participants apparently healthy, and were not smoking; use any medication, on a prescribed diet, pregnant, and working at night shifts.

Each of the participants should be habitual coffee consumers of 4-6 cups/day. The 45 participants in this study were divided into two groups, namely Group 1 for the participants who were treated firstly with regular coffee, then followed by decaffeinated coffee, and Group 2 for the participants who were treated firstly with decaffeinated coffee followed by regular coffee. The amount of regular coffee consumption in this research was 5 cups/day for 6 weeks, and the same goes for decaffeinated coffee. The total caffeine consumed during the regular and decaffeinated coffee period was $445 \mathrm{mg}$ and $40 \mathrm{mg}$ consecutively.

The SBP (Systolic Blood Pressure), DBP (Diastolic Blood Pressure), and HR (heart rate) values were the parameters used in this study. Participants measured their ambulant blood pressure and heart rate at 7:30 and 10:00 $\mathrm{AM}$ and 1:00, 5:30, and 10:30 PM in a day per week by random order. The results showed that the SBP and DBP values of regular coffee drinkers were higher compared to decaffeinated coffee drinkers (SBP value 110,9 $\mathrm{mmHg}$ and 109,4 mmHg), (DBP value 69,6 $\mathrm{mmHg}$ and $68,6 \mathrm{mmHg}$ ). The result goes the same for the mean arterial value $(83,4 \mathrm{mmHg}$ and $82,2 \mathrm{mmHg}$ ). This study showed that 30 of 45 subjects had a lower SBP and DBP when consuming decaffeinated coffee compared to when consuming regular coffee. The researcher stated that there is 
clear evidence that caffeine could elevate the blood pressure in subjects who had abstained from caffeine for at least 1 week (Dusseldorp et al., 1989). Besides, caffeine users who abstained from caffeine for 12-24 hours could produce a significant increase in blood pressure and a decrease in heart rate (Dusseldorp et al., 1989).

Grobbee (1991) conducted a 12 weeks doubleblind randomized study to evaluate the relation between caffeine, blood pressure, and serum lipids. This study carried out 69 participants with unspecified gender and characteristic. These participants were divided into two groups named Group 1 for participants who were treated with filtered decaffeinated coffee and an equal number of placebo tablets containing $75 \mathrm{mg}$ caffeine. Group 2 was placebo or control which was treated by decaffeinated coffee and an equal number of placebo tablets and did not contain caffeine. The amount of coffee that was given to the participants in Group 1 was 4-6 cups/day. The SBP, DBP, HR, and serum cholesterol values were the parameters used in this study. The results showed that the changes in SBP, DBP, and HR were not significantly different between the two groups. The SBP value net change between the regular and decaffeinated coffee groups was found higher in the sixth week $(2.2 \mathrm{mmHg})$.

The effect of caffeine through the administration of decaffeinated coffee and caffeine tablets was assessed by comparing the change value from the 3,6 , and 9 weeks respectively. The total, HDL, and LDL serum cholesterol were not affected significantly by caffeine. The same goes for apolipoprotein A-1 and apolipoprotein B. The researcher stated that this result was in line with their previous findings in a randomized trial which focused on the brewing method of coffee given in the intervention. Meanwhile, the blood pressure (SBP and DBP) and heart rate value also found not significantly different during 9 weeks of intervention. In conclusion, caffeine has no adverse effect on cardiovascular observed from the change in serum lipids, blood pressure, and heart rate in this study.

Superko et al. (1994) conduct 8 weeks randomized trial to investigate the effects of cessation of regular coffee consumption on ambulatory and resting blood pressure in men. This study carried out 186 men in middle age, and they were nonsmoker, normotensive, and habitual regular coffee consumers. The subject participants were divided into three groups, which are for regular coffee $(n=52)$, decaffeinated coffee $(n=51)$, and no coffee $(n=47)$. All groups were administered with a cup of coffee per day with unspecified caffeine content. The parameter of this study was the BP value in the morning after abstention from food, coffee, and vigorous physical activity.

The SBP, DBP, and HR values were measured in three periods, which are 900-1200, 1200-1500, and 1500-1800 hours. The statistical analysis among all 3 groups indicated a significant difference in SBP changes at 900 to 1200,1200 to 1500 , and 1500 to 1800 hours. Meanwhile, the significant differences in DBP were found from 1200 to 1500 , and 1500 to 1800 hours. In comparison, two groups that switched to decaffeinated coffee or discontinue regular coffee showed significant decreases in SBP at 3 time periods; 900 to 1200,1200 to 1500 , and 1500 to 1800 hours. Besides, the DBP value showed significant decreases for the non coffee group from 1200 to 1500 , and 1500 to 1800 hours period. Meanwhile, the DBP decrease in the decaffeinated coffee group was found from 1200 to 1500, and 1500 to 1800 hours period. In conclusion, based on statistical analysis, there was no significant difference in SBP, DBP, and heart rate between the three groups.

Karatzis et al. (2005) conducted a randomized, double-blind crossover study with 16 subject participants which consist of 8 males and 8 females. The participants included in this study should be healthy, normotensive, not obese, and did not suffer from diabetes, kidney, liver, or other metabolic disorder. The participants consumed a cup of warm instant coffee containing $80 \mathrm{mg}$ caffeine, or a cup of decaffeinated coffee within 10 minutes on 2 different days for 1 week apart. For these periods, participants were not allowed to consume regular products such as tea, chocolate, and soft drinks for at least 12 hours before the study. Hemodynamic measurements which consist of peripheral blood pressure, central blood pressure, wave reflection, and arterial stiffness, 
augmentation index, and arrival time were used as parameters in this study. The data showed that peripheral SBP did not change significantly after regular or decaffeinated coffee consumption, even though the baseline characteristics at the two sessions of the study did not differ significantly. The peripheral DBP significantly increased after regular administration (4 $\mathrm{mmHg}$ in different), while no change was observed after decaffeinated coffee consumption. Central SBP increased by almost $4 \mathrm{mmHg}$ after regular coffee consumption, and it was not significantly altered following decaffeinated coffee consumption.

Renda et al. (2012) reported a 2 days double-blind randomized trial using 110 subject participants. All of the participants included in the study were moderate coffee drinkers in health conditions. The participants were divided into two groups, one for participants who received $40 \mathrm{~mL}$ decaffeinated coffee added with $3 \mathrm{mg} / \mathrm{kg}$ caffeine, and the control group who received only decaffeinated coffee. The $\mathrm{BP}$ and HR measurements were conducted within 6 minutes intervals for 2 hours after coffee administration. The study was run early in the afternoon within 2 consecutive days. The parameters used in this study were HR, BP, plasma caffeine, and plasma catecholamines value. The baseline HR, as well as SBP and DBP were similar before regular or decaffeinated coffee administration (SBP: 132,6 \pm 12 compared to 131,6 $\pm 11 \mathrm{mmHg}$; DBP: $79,6 \pm 10 \mathrm{mmHg}$ compared with 78,6 $\pm 9 \mathrm{mmHg}$ ). The SBP and DBP values were both significantly higher only 18 minutes after regular coffee intake compared with decaffeinated coffee. This condition persisted until the end of the study. Most subjects who administered regular coffee experiencing an increase in BP (but some experiencing a decrease in BP) compared to subjects who administered decaffeinated coffee as a control. This result confirmed a wide intersubject variability in the BP response to coffee.

Azuamah and Esenwah (2013) evaluate the effect of decaffeinated coffee on the systolic blood pressure and pulse rate. This study designed as experimental analytic research with 103 subject participants aged between 15 and 30 years, and Body Mass Index (BMI) between 20 and 25. All of the subject participants were administrated with 1 cup of coffee (3,6 f decaffeinated coffee in $200 \mathrm{~mL}$ of water). The blood pressure was measured at 45 minutes before and after decaffeinated coffee administration. The mean SBP before the ingestion of decaffeinated coffee was $108,66 \mathrm{mmHg}$, which later this value decreased by $2,62 \%$ within 45 minutes after decaffeinated coffee ingestion to 105,81 mmHg. The mean pulse rate between before and after the ingestion of decaffeinated also showed the same results $(75,28$ to $73,07 \mathrm{bpm}$; reduction of 2,94\%). From these data, the null hypothesis was rejected since statistical analysis showed a significant difference in the SBP before and after decaffeinated coffee ingestion. Also, this study concluded that the ingestion of decaffeinated coffee produced a reduction in SBP and pulse rate.

Meera et al. (2015) conducted a randomized threesession crossover design the study to evaluate the short-term effects of espresso coffee on heart rate variability and blood pressure in habitual and nonhabitual coffee consumers. These 5 days study carried out 77 subject participants which consist of 38 habitual and 39 non-habitual coffee drinkers aged between 18 and 50 years. All of the subject participants took part in three laboratory sessions in randomized order (regular espresso, decaffeinated espresso, and warm water). The caffeine content of regular espresso was $256,8 \mathrm{mg} / \mathrm{cup}$, while the caffeine content of decaffeinated espresso was 36 $\mathrm{mg} /$ cup. As a parameter, HR and BP value during the rest period before and after ingestion coffee was measured.

All subjects were to drank the respective beverages maximum of 10 minutes. After that, subjects were allowed to rest, and continue to drank other beverages 50 minutes later. The HR, SBP, and DBP were measured at 30 minutes after espresso ingestion.

The HR decrease was higher after regular espresso ingestion compared with decaffeinated espresso in habitual consumers. The same goes for HR decrease after regular espresso and decaffeinated espresso in non-habitual coffee consumers. The SBP decrease was found higher after decaffeinated espresso ingestion compared to regular espresso in habitual coffee consumers. The same result goes 
for SBP decrease in non-habitual coffee consumers. The DBP decrease was found higher after decaffeinated coffee ingestion in habitual coffee consumers, and so on with the decrease of DBP in non-habitual coffee consumers. Meanwhile, the DBP increased higher after regular espresso compared to decaffeinated espresso in non-habitual coffee consumers. However, statistical analysis from a total of 77 participants revealed that no significant differences regarding any of the physiological variables including HR, SBP, and DBP before and after the consumption of regular espresso, decaffeinated espresso, and warm water. Besides, the study suggests that no evidence is found for specific short-term effects of regular espresso on vagal activity (the baseline activity of vagus nerve to maintain several body functions at rest, including heart rate, lungs, and digestion) in healthy subjects.

This review is aimed to observe the relation between caffeinated and decaffeinated coffee and the risk of hypertension. However, the research article reviewed in this study can have several limitations. The first one is that the observation of the acute effect of caffeine either in the form of coffee (regular or decaffeinated) or capsules may not reflect long-term effects since the tolerance of caffeine can change in every participant (Van Dam et al., 2020). Second, although longer-term randomized trials are desirable, such studies are sometimes not feasible due to cost and practical consideration. However, such studies using selfreport in measures the coffee consumption frequency are highly accurate and reproducible. Several parameters that lead to error or bias in the draw the conclusion including the variation in cup size, brew strength, type of coffee bean, and the number of other components added to the coffee (e.g sugar, creamer, milk) (Van Dam et al., 2020).

Concerns regarding coffee and caffeine intake that may increase the risk of hypertension and cardiovascular disease have existed for years, but recently, the evidence health benefit of coffee also appeared. Coffee is known to contain hundreds of other biologically active phytochemicals despite caffeine, such as chlorogenic acid and ligands, alkaloid trigonelline, melanoidins (formed during roasting), and a modest amount of minerals such magnesium, potassium, and vitamin (Colombo and Papetti, 2020). These compounds may contribute to health improvement in humans, including the intestinal, cardiovascular, cognitive, and other physiological properties. Besides, most of the previously mentioned chemical compound of coffee has antioxidant properties and may reduce oxidative stress which leads to the various health problems. Contrarily, a biological compound such as diterpene cafestol which presents in unfiltered coffee could increase serum cholesterol. This suggests that the incidence of a health problem such as hypertension could be caused by other compounds or factors and not caffeine itself (Van Dam et al., 2020).

\section{CONCLUSION}

Based on clinical studies in general or unspecified subjects, consumption of regular coffee tends to increase the DBP and SBP more compared to decaffeinated coffee. The DBP and SBP increased after 18, 20 and 30 minutes after coffee consumption.

Meanwhile, consumption of decaffeinated coffee could reduce the SBP from the initial value. Besides, it was found that regular coffee induces a rise of plasma catecholamines significantly higher than the changes after decaffeinated coffee. In the non-smoker subjects, regular coffee might increase the heart rate compared to decaffeinated coffee. Besides, the subjects tend to have a lower SBP and DBP when consuming decaffeinated coffee compared to when consuming regular coffee.

Meanwhile, the catecholamines were found not significantly different in both type coffee consumption. However, there is study which conclude that regular coffee increase catecholamines. Based on coffee drinking habits, it was found that regular coffee intake might increase the heart rate compared to decaffeinated coffee while decaffeinated coffee could to significant decreases in SBP compared to regular coffee in habitual coffee drinkers. In the moderate coffee drinkers, regular coffee leads to both an increase and a decrease in BP from the initial value compared to decaffeinated coffee. In the nonhabitual coffee drinkers, the heart rate was found 
decreased and DBP was found increased from the baseline after regular coffee consumption compared to decaffeinated coffee.

In addition, on subjects with high activity (exercise), it was found that regular or decaffeinated coffee gives a similar cardiovascular effect in healthy subjects compared to placebo.

From several cohort studies with a different population (two stages of hypertension, postmenopausal women, and Mediterranean subjects) that are reviewed in this study, it was found that consumption of regular coffee is negatively associated with the incidence of hypertension in the subject with lower blood pressure (less than $<160$ and DBP $<100 \mathrm{mmHg}$ ). In the postmenopausal subjects, no consistent association was found between regular and decaffeinated coffee intake and the risk of hypertension. In a more specific cohort, which is the Mediterranean cohort, it was found that neither regular nor decaffeinated coffee consumption was significantly associated with the incidence of hypertension.

A systematic review regarding the effect of regular and decaffeinated coffee could be improved by integrating more factors such as the relationship between decaffeination technology, amount of caffeine, and other hypertension markers despite blood pressure, heart rate, and catecholamines. Several parameters of hypertension that can be used for further research include C-reactive protein, fibrinogen, plasminogen activator inhibitor-1, aldosterone, renin, b-type natriuretic peptide, and $\mathrm{N}$-terminal pro atrial natriuretic peptide, homocysteine, and urinary albumin/creatinine ratio to evaluate the effect of regular or decaffeinated coffee.

\section{REFERENCES}

Ammon, H.P.T., Bieck, P.R., Mandalaz, D., Verspohl, E.J. 1983. Adaptation of blood pressure to continuous heavy. Blackwell Scientific Publications. 15, pp.701-706.

Azuamah, Y. and Esenwah, E.C. 2013. Effect of decaffeinated coffee on the systolic blood pressure and pulse rate. International Journal of Environmental Health and Human Development. 14(1), pp.39-43.

Butt, M.S., Ahmed, A., Sultan, M.T., Imran, A., Yasin, M., Imran, M. 2011. Evaluating the effect of decaffeination on nutritional and antioxidant status of different coffee brands. Internet Journal of Food Safety. 13, pp.198207.

Colombo, R. and Papetti, A. 2020. Decaffeinated coffee and its benefits on health: focus on systemic disorders. Critical Reviews in Food Science and Nutrition. 0(0), pp.1-17.

De Paula J, Farah A. 2019. Caffeine consumption through coffee: content in the beverage, metabolism, health benefits and risks. Beverages. 5(2), pp.37.

Farah, A. 2009. Functional and speciality beverages. in: Paquin, P. ed. Beverage technology. Cambridge: Woodhead Publishing, pp.371-395.

Farah, A. 2018. Achieving sustainable cultivation of coffee. in: lashermes, P. ed. Nutritional and Health Effect of Coffee. Cambridge: Burleigh Dodds Science Publishing Limited, pp.1-31.

Greenberg, J.A, Chow, G., Ziegelstein, R.C. 2008. Caffeinated coffee consumption, cardiovascular disease, and heart valve disease in the elderly (from the Framingham Study). American Journal of Cardiology. 102(11), pp.1502-1508.

Grobbee, D.E., Arnette, A.A. 1991. Caffeine, blood pressure, and serum lipids. American Journal of Clinical Nutrition. 53, pp.971-975.

Heilmann, W. 2008. Decaffeination of coffee. in : Vitzhtum, O.G. ed. Coffee: recent developments. New Jersey: Wiley Blackwell, pp.108-124.

Karatzis, E., Papaioannou, T.G., Aznaouridis, K., Karatzi, K., Stamatelopoulos, K., Zampelas, A., Papamichael, C., Lekakis, J., Mavrikakis, M. 2005. Acute effects of caffeine on blood pressure and wave reflections in healthy 
subjects: should we consider monitoring central blood pressure?. International Journal of Cardiology. 98(3), pp.425-430.

Meera, S.S., Shankar, R.G., Girimaji, S.C., Seshadri, S.P., Philip, M., Shivashankar, N. 2015. Short-term effects of espresso coffee on heart rate variability and blood pressure in habitual and non-habitual coffee consumers: a randomized crossover study. Nutritional Neuroscience. 0(0), pp.1-5.

Navarro, A.M., Martinez-Gonzalez, M.A., Gea, A., Ramallal, R., Ruiz-Canela, M., Toledo, E. 2019. Coffee consumption and risk of hypertension in the SUN project. Clinical Nutrition. 38(1), pp.389-397.

Pietsch, A. 2017. Decaffeination-process and quality. in: Folmer, B. ed. The craft and science of coffee. Massachusetts: Academic Press, pp.225-143.

Poole, R., Kennedy, O.J., Roderick, P., Fallowfield, J.A., Hayes, P.C., Parkes, J. 2017. Coffee consumption and health: umbrella review of meta-analyses of multiple health outcomes. British Medical Journal. 359, pp.1-17.

Prakash, R., Kaushik, V.S. 1988. Acute effect of decaffeinated coffee on heart rate, blood pressure, and exercise performance in healthy subjects. Journal of the National Medical Association. 80(1), pp.71-74.

Ramalakshmi, K., Raghavan, B. 1999. Caffeine in coffee: its removal. why and how?. Critical Reviews in Food Science and Nutrition. 39(5), pp.441-456.

Renda, G., Zimarino, M., Antonucci, I., Tatasciore, A., Ruggieri, B., Bucciarelli, T., Prontera, T., Stuppia, L., De Caterina, R. 2012. Genetic determinants of blood pressure responses to caffeine drinking. American Journal of Clinical Nutrition. 95(1), pp.241-248.

Rhee, J.J., Qin, F.F., Hedlin, H.K., Chang, T.I., Bird, C.E., Zaslavsky, O., Manson, J.E., Stefanick, M.L., Winkelmayer, W.C. 2016.
Coffee and caffeine consumption and the risk of hypertension in postmenopausal women. American Journal of Clinical Nutrition. 103(1), pp.210-217.

Smits, P. 1985. Regular and decaffeinated coffee. Blood Pressure. 19, pp.852-854.

Superko, H.R., Myll, J., DiRicco, C., Williams, P.T., Bortz, W.M., Wood, P.D. 1994. Effects of cessation of caffeinated-coffee consumption on ambulatory and resting blood pressure in men. The American Journal of Cardiology. 73(11), pp.780-784.

Temple, J.L., Bernard, C., Lipshultz, S.E., Czachor, J.D., Westphal, J.A., Mestre, M.A. 2017. The safety of ingested caffeine: a comprehensive review. Frontiers in Psychiatry. 8, pp.1-19.

Van Dam, R.M., Hu, F.B., Willett, W.C. 2020. Coffee, caffeine, and health. New England Journal of Medicine. 383(4), pp.369-378.

Van Dusseldorp, M., Smits, P., Thien, T., Katan, M.B. 1989. Effect of decaffeinated versus regular coffee on blood pressure : a 12-week, double-blind trial. Hypertension. 14(5), pp.563-569.

Wang, X., Kattan, M.W. 2020. Cohort studies : design, analysis, and reporting. American College of Chest Physicians. 158(15), pp.572578.

Zhang, Z., Hu, G., Caballero, B., Appel, L., Chen, L. 2011. Habitual coffee consumption and risk of hypertension: a systematic review and meta-analysis of prospective observational studies. American Journal of Clinical Nutrition. 93(6), pp.1212-1219. 